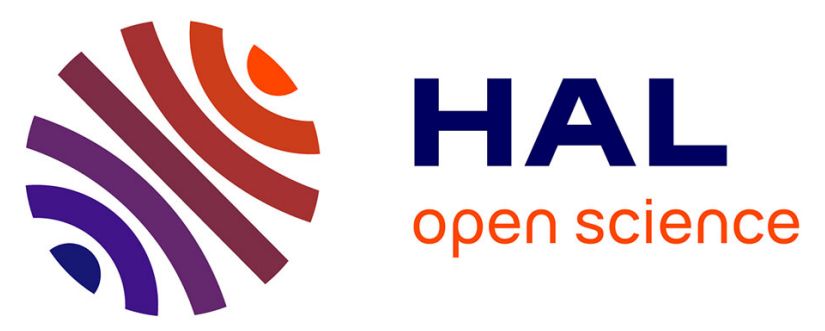

\title{
Historical ecology of Mediterranean forests: Land use legacies on current understorey plants differ with time since abandonment and former agricultural use
}

Juliet Abadie, Jean-Luc Dupouey, Aline Salvaudon, S. Gachet, Noémie Videau, Catherine Avon, Jérôme Dumont, Thierry Tatoni, L. Bergès

\section{To cite this version:}

Juliet Abadie, Jean-Luc Dupouey, Aline Salvaudon, S. Gachet, Noémie Videau, et al.. Historical ecology of Mediterranean forests: Land use legacies on current understorey plants differ with time since abandonment and former agricultural use. Journal of Vegetation Science, 2021, 32 (1), pp.1-13. $10.1111 /$ jvs.12860 . hal-03168867

\section{HAL Id: hal-03168867 https://hal.science/hal-03168867}

Submitted on 19 Apr 2021

HAL is a multi-disciplinary open access archive for the deposit and dissemination of scientific research documents, whether they are published or not. The documents may come from teaching and research institutions in France or abroad, or from public or private research centers.
L'archive ouverte pluridisciplinaire HAL, est destinée au dépôt et à la diffusion de documents scientifiques de niveau recherche, publiés ou non, émanant des établissements d'enseignement et de recherche français ou étrangers, des laboratoires publics ou privés. 


\title{
Historical ecology of Mediterranean forests: Land use legacies on current understorey plants differ with time since abandonment and former agricultural use
}

\author{
Juliet Abadie ${ }^{1}$, Jean-Luc Dupouey ${ }^{2}$, Aline Salvaudon ${ }^{3}$, Sophie Gachet ${ }^{4}$, Noémie Videau ${ }^{5}$, \\ Catherine Avon ${ }^{6}$, Jérôme Dumont ${ }^{7}$, Thierry Tatoni ${ }^{4}$, Laurent Bergès ${ }^{8}$ \\ ${ }^{1}$ IRSTEA RECOVER, Aix-en-Provence Cedex \\ 5, France \\ ${ }^{4}$ UMR IMBE, Avignon Université, CNRS, IRD, \\ Aix Marseille Université, Marseille Cedex \\ 20, France \\ ${ }^{7}$ BayWa r.e. France SAS, Paris, France

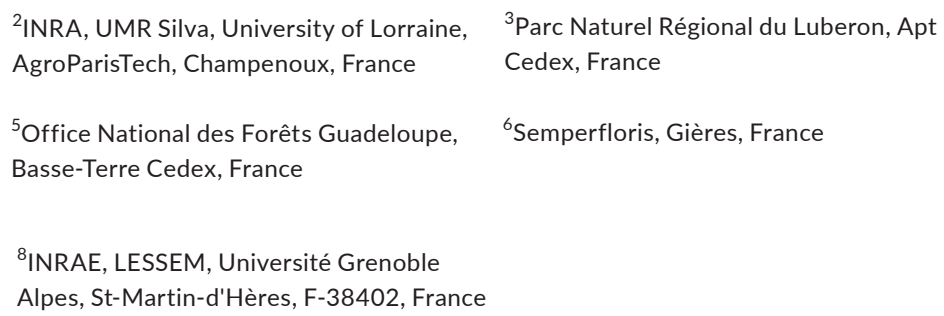

Abstract

Questions: Land use legacies in current forest understorey vegetation, thoroughly studied in temperate regions, were investigated in a Mediterranean context. We tested the effect of three historical variables on current forest plant communities and traits: forest temporal continuity (ancient: forested before 1860, recent: refor-ested after 1860, and very recent forest: reforested after 1958) and type of land use in 1860 and 1958 (forest, pasture or arable land).
\end{abstract}

Location: The Regional Natural Park of Luberon (southeastern France).

Methods: We used a comprehensive vegetation plot database (473 species in 1,429 plots). Species' response to historical variables was tested with logistic regressions, and the relationship between plant traits and historical variables was analysed with RLQ and fourth-corner analyses.

Results: Among all studied species, 250 responded to forest temporal continuity, 208 to 1860 land use, and 246 to 1958 land use. Species associated with ancient forests were more frequently forest specialists or forest edge species, shade-tolerant and perennials, while species associated with recent and very recent forests were more frequently annuals, anemochorous and heliophilous species. Species exhibited dif-ferent traits and ecological preferences according to the type of land use prior to forest: therophytes were more frequent on former arable land while chamaephytes were more frequent on former pasture. Trait responses to 1860 and 1958 land uses were globally consistent.

Conclusions: The effect of forest temporal continuity and past land use on forest understorey communities was consistent with other studies in northern Europe or northern America, which suggests that the same ecological processes apply in temperate lowland and Mediterranean regions. This study highlights a succession of plant communities in the long term and different trajectories of succession according to the type of former agricultural use. The long-term legacies of past land use in current forest plant communities highlight the importance to preserve ancient forests, where typical forest species can be maintained.

\section{KEYWORDS}

agricultural use, ancient forest, ecological preference, forest continuity, historical ecology, life-history traits, mediterranean forest, recent forest, secondary succession 


\section{1 | INTRODUCTION}

Land use change across time led to an increase in forests with lower temporal continuity (recent forests) and a decrease in long-established forests (ancient forests). Former agricultural use affects current forest understorey vegetation (Flinn \& Vellend, 2005; Hermy $\&$ Verheyen, 2007), even centuries after abandonment (Dupouey, Dambrine, Laffite, \& Moares, 2002; Plue et al., 2008). Dispersal and recruitment limitations of forest-dwelling species generally explain the difference in understorey plant composition between ancient and recent forests (Baeten, Hermy, \& Verheyen, 2009; Flinn \& Vellend, 2005; Graae, Hansen, \& Sunde, 2004; Hermy \& Verheyen, 2007). Plant species occurring more frequently in ancient forests have short-distance dispersal mechanisms (barochorous, autochorous and myrmecochorous species, vegetative reproduction) and no or poor soil seed bank; they are frequently small, herbaceous (geophytes or hemicryptophytes), stress-tolerant and have the same ecological preferences as true forest specialists (shade-tolerant, mesophilous, neutrophilous to moderately acid-tolerant; Bergès et al., 2016; Bossuyt, Heyn, \& Hermy, 2002; Brunet, Frenne, Holmstrom, \& Mayr, 2012; Kimberley, Blackburn, Whyatt, Kirby, \& Smart, 2013; Sciama, Augusto, Dupouey, Gonzalez, \& Dominguez, 2009). Therefore, ancient forests have a high conservation value, as they support species with poor colonisation capacities and no soil seed bank, which are thus more vulnerable to forest habitat loss (De Frenne et al., 2011; Flinn \& Vellend, 2005; Hermy \& Verheyen, 2007).

Compared to temperate forests, few studies have explored the effect of forest temporal continuity on the current understorey vegetation of Mediterranean forests (Abadie, Avon, et al., 2018; Amici et al., 2013; Basnou, Vicente, Espelta, \& Pino, 2016; Kouba, Martinez-Garcia, Frutos, \& Alados, 2015). The Mediterranean region is one of the few world biodiversity hotspots (Gauquelin et al., 2018; Grove \& Rackham, 2001; Médail \& Diadema, 2009). Climate is a main component of the Mediterranean specificity: hot and dry summers with mild and humid winters have led to the development of specific soils subject to erosion and leaching (Gauquelin et al., 2018), and a higher risk of natural fires. The Mediterranean climate also favoured species adapted to a high daily temperature amplitude and long water stress periods. The topography is often rugged and constrains the space available to cultivate land. Farmers adapted to this constraint and used this land with terraced cropland and extensive grazing, developing an agro-sylvo-pastoral system which characterised the traditional landscape of the Mediterranean area
(Taillefumier \& Piegay, 2003). Studies in the Mediterranean region showed that woody species were poorly influenced by forest continuity (Basnou et al., 2016). The richness of light-demanding species dropped with increasing successional age of the forest (Amici et al., 2013), while the last centuries intensive and widespread agricultural use may have led to a loss in late-successional species (Kouba et al., 2015). However, except Abadie, Avon, et al. (2018), existing studies on forest temporal continuity only focused on the medium term, i.e. the last 50 years.

Forest cover has increased extensively in France since the 19th century (Cinotti, 1996; Mather, Fairbairn, \& Needle, 1999), especially in less accessible areas of the Mediterranean region (Abadie, Dupouey, et al., 2018; Koerner, Cinotti, Jussy, \& Benoît, 2000). Forests mostly developed on former pastures or arable land (Koerner et al., 2000) but the long-lasting effects of different forms of agriculture on current forest ecosystems have been much less investigated than the simple dichotomy of ancient versus recent forests (Hermy \& Verheyen, 2007). Different forms of agriculture can have distinct long-term effects on soils and environmental conditions and can result in contrasting understorey plant successions in post-agricultural forests (Dyer, 2010; Holmes \& Matlack, 2018; Koerner, Dupouey, Dambrine, \& Benoit, 1997). Soils of former cropland were ploughed, levelled and enriched by nutrient inputs while soils of former pasture were trampled and depleted through mineral matter export (Flinn, Vellend, \& Marks, 2005; Stover \& Marks, 1998). Alternatively, former pastures may also have been fertilised with dung, while an overexploitation of crops might have impoverished soils through erosion and depletion (Stover \& Marks, 1998). In addition, pasturing could allow forest species to survive in refugia such as rock outcrops (Holmes \& Matlack, 2018), as a marginal component of grassland communities, or as belowground organs such as rhizomes (Bellemare, Motzkin, \& Foster, 2002; Stover \& Marks, 1998). Consequently, forests on former cropland are generally more nutrient-rich (nitrogen and phosphorus) and support a higher plant species richness with more nitrophilous species, while forests on former pasture have poorer soils and support more stress-tolerant plant communities (Dupouey et al., 2002; Dyer, 2010; Koerner et al., 1997). In the Mediterranean region, forests were also historically grazed; thus, the legacies of former pasture in current forest plant communities might be difficult to detect. In contrast, former cropland was often established on artificial terraces, which thoroughly modified soil structure and nutrient availability (Abadie, Avon, et al., 2018). The long-term environmental effects of contrasting agricultural 
histories on forest understorey plant communities and traits thus remain to be clarified, in particular in Mediterranean regions where crops and pastures were copiously represented (Abadie, Avon, et al., 2018).

Our main objective was to assess the long-term effects of historical agriculture on current forest understorey vegetation in a Mediterranean context over the past 150 years. We explored the long-lasting effects of two types of former agricultural use (pasture or arable land), at two different dates (1860 and 1958) and of time since agricultural abandonment (recent or very recent forests) on forest understorey vegetation through a plant trait-based approach, using long-established stands without signs of agricultural use (i.e. ancient forests) as a control. First, we hypothesized that the differences in understorey plant communities between formerly cultivated sites and ancient forests would be higher than the difference between formerly pastured sites and ancient forests, because cultivation exhibits higher levels of understorey vegetation and soil disturbances (Singleton, Gardescu, Marks, \& Geber, 2001). We expected that differences in plant traits between former cropland and pastures persisted due to contrasting historical environmental filtering (Holmes \& Matlack, 2018). Second, we assumed that the legacies of 1958 land use on current understorey plant communities and traits would be more detectable than the legacies of 1860 land use, under the hypothesis that plant communities in post-agricultural forests gradually converge towards ancient forest communities. Third, consistent with these two hypotheses, we expected that floristic differences between pasturing and cultivation would be more pronounced in recent forests developed after 1958 compared to forests developed between 1860 and 1958 (Holmes \& Matlack, 2018).

\section{2 | METHODS}

\section{1 | Study area}

The Regional Natural Park of Luberon (PNRL) is a rural area located in the eastern French Mediterranean region $\left(43^{\circ} 39^{\prime}-44^{\circ} 02^{\prime}\right.$ $\left.\mathrm{N}, 4^{\circ} 58^{\prime}-5^{\circ} 55^{\prime} \mathrm{E}\right)$ and covers 195,413 ha. Climate is typically Mediterranean with mild and humid winters and hot and dry summers (annual precipitation $740 \mathrm{~mm}$ and temperature $12.7^{\circ} \mathrm{C}$ according to the 1981-2010 Aurelhy means from Meteo-France). Lithology is mostly calcareous (95\%) and elevation ranges from 55 to $1,210 \mathrm{~m}$. More than half of the area is covered by forests (55\%), mostly composed of holm oak (Quercus ilex-22\%), downy oak (Q. pubescens-23\%) and Aleppo pine (Pinus halepensis-18\%) stands. Most of the forests are privately owned (71\%) and managed differently according to the owners. Historically, forests were mostly coppiced for charcoal, firewood and tanning (oak bark). In the mid-19th century, the socioeconomic and political context led to land abandonment and a gradual forest recovery on former pastures and arable land (Abadie, Dupouey, et al., 2018; Chalvet, 2006; Fourchy, 1963; Gilbert, 1989).

\section{2 | Forest continuity and past land uses}

The present forest cover was extracted from the National Forest Inventory (http://inventaire-forestier.ign.fr/spip/spip.php?rubri que53; 1:25,000), digitised from the orthophotographs of 2005 (western part) and 2009 (eastern part). We extracted past land uses from two historical sources:

- 1860: The "État-Major" map (EM map; 1858-1861 in the PNRL; 1:40,000), digitised by Salvaudon, Hamel, Grel, Rossi, \& Vallauri, (2012) following Favre et al. (2013), with a median position error of $26 \mathrm{~m}$ after georeferencing and correction;

- 1958: Historical aerial photographs taken between 1953 and 1958, photo-interpreted for each vegetation plot.

The use of these two sources allowed us to reconstruct land use transitions over the whole period (Abadie, Dupouey, et al., 2018). From these data, we defined the temporal continuity of the current forest patches (Table 1). Ancient forests (AF) were those present in 1860 and 1958; recent forests (RF) developed between 1860 and 1958, very recent forests (VRF) developed after 1958 and temporally deforested forests (DEF) were forests in 1860 but not in 1958 . We processed maps using ArcGIS 10.3 (ESRI France).

We had to consider that no turnover in land cover occurred between the dates of the different maps. However, the EM map was made after a long period of deforestation, meaning that forest patches were probably already long established at that time. Moreover, the south of France is in a net forest recovery context since the mid-19th century (Abadie, Dupouey, et al., 2018). It is therefore unlikely that significant forest conversion occurred since then.

\section{3 | Vegetation plots}

Vegetation plots were extracted from an existing floristic database, SILENE (http://flore.silene.eu; see Appendix S1 for details). We dropped all plots with not enough location accuracy, sampled before $\mathbf{2 0 0 0}$ or on marginal acidic substrates, containing less than ten species, and located at a distance of less than five metres from the nearest road or walk pathway (Appendix S1). We analysed plots situated in forest that was forest, arable or pasture in 1860 or in 1958 (Table 1, Figure 1). We only retained species present in more than $1 \%$ of the plots, resulting in a final dataset of 473 species and 1,429 plots. The vegetation nomenclature follows TAXREF v.8 (Gargominy et al., 2014).

\section{4 | Plant traits and ecological preferences}

We collected plant functional traits and ecological preferences from four existing databases: BASECO, in which all data were retrieved in the French Mediterranean area (Gachet, Vela, \& Tatoni, 2005); 
TAB LE 1 Past land use in 1860 and 1958, forest continuity and resulting land use trajectories for plots forested in 2010

\begin{tabular}{|c|c|c|c|c|c|}
\hline 1860 land use & $\begin{array}{l}1958 \text { land } \\
\text { use }\end{array}$ & $\begin{array}{l}\text { Forest temporal } \\
\text { continuity }\end{array}$ & Land use trajectory & $\begin{array}{l}\text { Percentage within } \\
\text { current forest area }\end{array}$ & $\begin{array}{l}\text { Number } \\
\text { of plots }\end{array}$ \\
\hline Forest & Forest & AF & $\mathrm{AF}$ & 41 & $436(31 \%)$ \\
\hline Arable & Forest & RF & RF on arable land & 12 & $234(16 \%)$ \\
\hline Pasture & Pasture & VRF & VRF on pasture & 7 & $152(11 \%)$ \\
\hline Pasture & Arable & VRF & VRF on pasture then arable land & 2 & $16(1 \%)$ \\
\hline Arable & Arable & VRF & VRF on arable land & 10 & $64(4 \%)$ \\
\hline Forest & Pasture & DEF & DEF to pasture & 3 & $91(6 \%)$ \\
\hline Forest & Arable & DEF & DEF to arable land & 1 & $6(0 \%)$ \\
\hline
\end{tabular}

Abbreviations: AF, ancient forest; RF, recent forest; VRF, very recent forest; DEF, temporally deforested between 1860 and 2010.
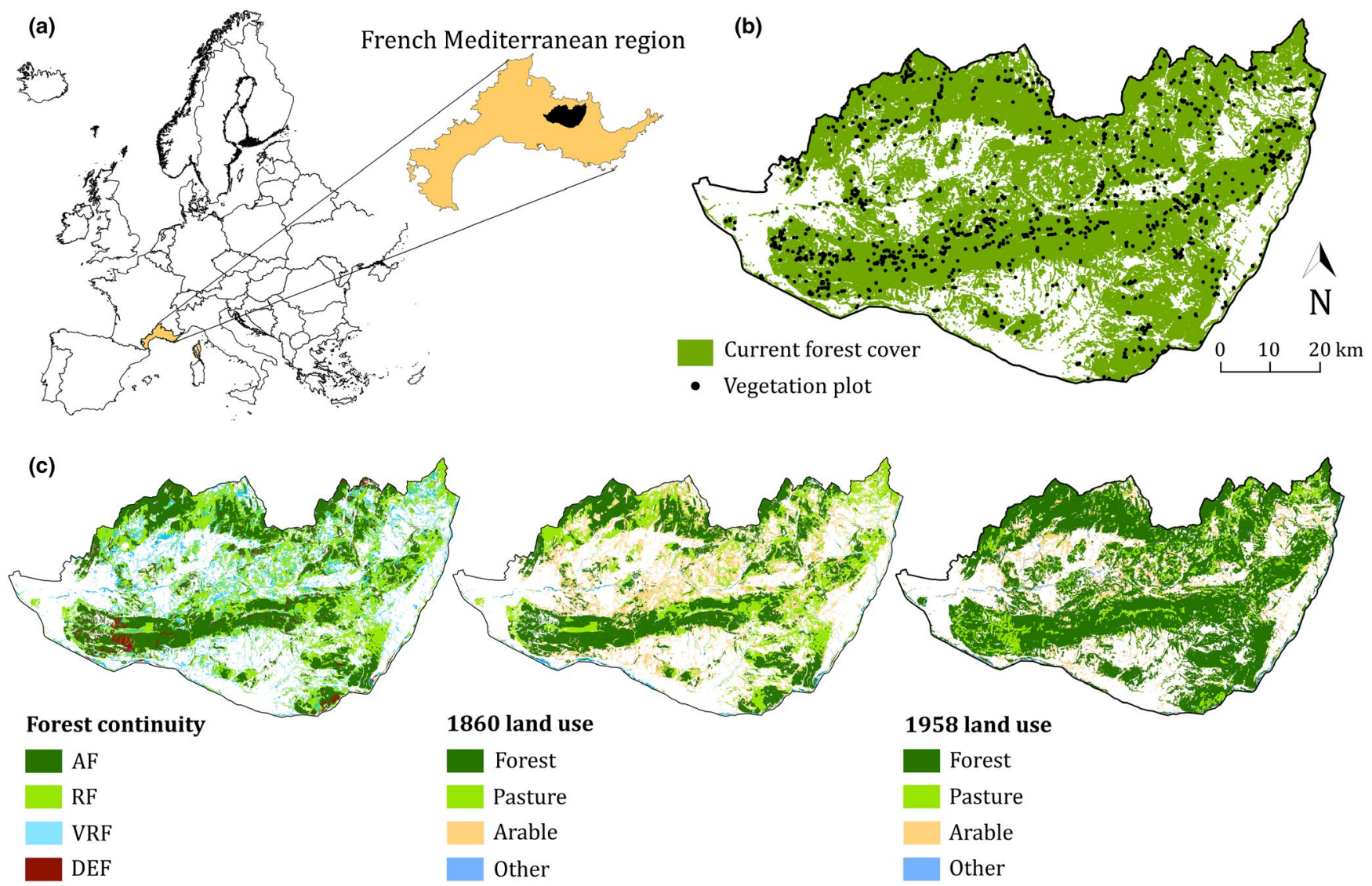

FIGURE 1 (a) Location of the study area within the French Mediterranean region; (b) vegetation plot distribution within the study area; and (c) maps of the three historical variables used in the models. AF: forest present in 1860, 1958 and 2010; RF: forest developed between 1860 and 1958; VRF: forest developed after 1958; DEF: forest in 1860 and 2010 but not in 1958

Baseflor, a national database of functional traits and ecological preferences (Julve, 1998); Pignatti for ecological preferences (Guarino, Domina, \& Pignatti, 2012; Pignatti, Menegoni, \& Pietrosanti, 2005); and the French Mediterranean flora (Tison, Jauzein, \& Michaud, 2014) (Table 2, Appendix S2).

We selected plant functional traits that responded to past land use in previous studies: Raunkiær's life form, vegetative reproduction, flowering phenology, longevity, dispersal mode and potential maximum height. The specific leaf area (SLA) recorded in European trait databases (Biolflor, LEDA) was not considered suitable in a Mediterranean context because of the climate specificity. Instead, we created a categorical trait for leaf size (Table 2). We also used leaf type as a proxy for plant life strategy (Table 2), and life strategy of Grime (Hodgson, Wilson, Hunt, Grime, \& Thompson, 1999).

Ecological preferences were also analysed as a proxy for ecological conditions: we used the indicator values of Ellenberg for light, 
TABLE 2 Life-history traits and ecological preferences retrieved from databases and flora

\begin{tabular}{|c|c|c|}
\hline Traits & Description & Source \\
\hline \multicolumn{3}{|l|}{ Functional traits } \\
\hline $\begin{array}{l}\text { Raunkiær life } \\
\text { form }\end{array}$ & $\begin{array}{l}5 \text { classes: Chamaephytes }(\text { CHAM) • Geophytes } \\
\text { (GEO)•Hemicryptophytes } \\
(\text { HEMI)•Phanerophytes }(\text { PHAN)•Therophytes } \\
(\text { THERO) }\end{array}$ & $\begin{array}{l}\text { BASECO, Baseflor, } \\
\text { Pignatti, Med Flora }\end{array}$ \\
\hline $\begin{array}{l}\text { Grime life } \\
\text { strategy }\end{array}$ & $\begin{array}{l}\text { C (competitive), S (stress-tolerant), R (ruderal), } \\
\text { CS, SC, CR, RC, SR, RS, CSR }\end{array}$ & BASECO \\
\hline Leaf type & $\begin{array}{l}\text { Malacophyllous (MALACO)•Microphyllous } \\
(\text { MICRO)•Graminaean } \\
(\text { GRAM)•Sclerophyllous \& laurel-like } \\
\text { (SCLERO)•Needles, Scales, Spines \& } \\
\text { Succulent (NEE) }\end{array}$ & BASECO \& Author \\
\hline Leaf size & $\begin{array}{l}5 \text { classes: } 1 \text { : very small; } 2: \text { small; } 3: \text { medium; } 4 \text { : } \\
\text { large; } 5 \text { : very large }\end{array}$ & Author \\
\hline $\begin{array}{l}\text { Vegetative } \\
\text { reproduction }\end{array}$ & $\begin{array}{l}\text { Yes (rhizome, bulb or tuber)•No (no vegetative } \\
\text { reproduction structure) }\end{array}$ & BASECO \\
\hline $\begin{array}{l}\text { Flowering } \\
\text { phenology }\end{array}$ & $\begin{array}{l}3 \text { variables: month of beginning (FL.BEG); } \\
\text { month of end (FL.END); duration of flowering } \\
\text { season (number of months) (FL.DUR) }\end{array}$ & Med Flora \\
\hline Longevity & $\begin{array}{l}3 \text { classes: Annuals (AN)•Biennials } \\
(\text { BISAN)•Perennials (PER) }\end{array}$ & BASECO \& Med Flora \\
\hline Dispersal mode & $\begin{array}{l}5 \text { classes: Anemochores } \\
(\text { ANEMO)•Autochores, Barochores \& } \\
\text { Hydrochores (BARO)•Dyszoochores \& } \\
\text { Endozoochores (ENDOZOO)•Epizoochores } \\
(\text { EPIZOO)• Myrmecochores (MYRMECO) }\end{array}$ & Baseflor \\
\hline Height & Potential maximum height (log). From 1.5 to 8.1 & Med Flora \\
\hline \multicolumn{3}{|c|}{ Ecological preferences } \\
\hline $\begin{array}{l}\text { Habitat } \\
\text { preference }\end{array}$ & $\begin{array}{l}\text { FOREST: forest species; EDGE: forest edge } \\
\text { species (thicket, heath and garrigue, clearings } \\
\text { and forest edges, matorral, megaphorbia, } \\
\text { forest herbaceous border); OPEN: open- } \\
\text { habitat species }\end{array}$ & $\begin{array}{l}\text { Adapted from } \\
\text { Baseflor }\end{array}$ \\
\hline $\begin{array}{l}\text { Light indicator } \\
\text { value }\end{array}$ & From 2 (sciaphilous) to 11 (heliophilous) & Pignatti \\
\hline Soil moisture IV & From 1 (hygrophilous) to 10 (xerophilous) & $"$ \\
\hline Nitrogen IV & From 1 (oligotrophic) to 9 (nitrophilous) & $"$ \\
\hline
\end{tabular}

nitrogen and soil moisture adapted to the Mediterranean species (Guarino et al., 2012; Pignatti et al., 2005). We also used the preferential habitat of the species (forest, forest edge, open-habitat) using Baseflor (Julve, 1998; Table 2).

\section{5 | Analysis}

We determined the preference of individual forest plant species to past land use (forest, pasture or arable in 1860 or 1958) or to forest temporal continuity (AF, RF, VRF or DEF) with logistic regressions (Bergès et al., 2016), conducted separately for each historical variable and controlling for ecological variations due to climate, topography, soil type, stand type and landscape context. The significance of the three historical variables (1860 land use, 1958 land use, and temporal continuity) was determined using the decrease in AIC criteria value $(\triangle \mathrm{AIC}>2)$ between a model including eight environmental covariates: dominant tree species, vegetation range, soil productivity, forest ownership, elevation, northness, slope, and distance from edge, and the same model including, in addition, the historical variable to be tested (see Appendix S3 for details).

We performed a canonical correspondence analysis (CCA) (Legendre \& Legendre, 1998) to test whether the two past land uses (1860 and 1958) and forest temporal continuity (AF, RF, VRF, DEF) had an effect on current plant composition, separately for each of the three variables with the vegan $R$ package ( $R$ Core Team, R Foundation for Statistical Computing, Vienna, Austria). We then used a combination of 1860 and 1958 land uses, so that we could jointly assess the three historical variables (variable "land use trajectory", see Table 1). For each case, we assessed the significance of the effect of the explanatory variable with a permutation test and 
represented the CCA factorial map using the ade4 R package (Dray $\&$ Dufour, 2007).

We tested the relationship between traits and historical variables using RLQ and fourth-corner analysis (Bergès et al., 2017; Dray et al., 2014). We tested the significance of the RLQ with a randtest function and tested the significance of each trait versus each historical variable with a fourth-corner analysis using the function fourthcorner.rla (Dray et al., 2014). We carried out statistical analyses using R software v. 3.2.5 (R Core Team, 2017).

Among the traits tested, we could not use the Grime's life strategy or the vegetative reproduction capacity in the RLQ analysis because of too many missing values.

\section{3 | RESULTS}

\section{1 | Species preference}

Among the 473 species in the whole dataset, 442 species were analysed in the logistic regressions (Appendix S4): 208 were significantly influenced by 1860 land use with 58 species preferentially found in already existing forest (1860-FS), 51 species in former pasture (1860-Pas-S) and 99 species in former arable land (1860Ara-S); 246 were significantly influenced by 1958 land use with 78 species preferentially found in already existing forest (1958-FS), 99 species in former pasture (1958-Pas-S) and 69 species in former arable land (1958-Ara-S). Finally, 258 were significantly influenced by forest temporal continuity with 57 species preferentially found in ancient forest (AFS), 37 species in recent forest (RFS), 77 species in very recent forest (VRFS) and 87 species in forest of 1860 that was not mapped as forest in 1958 (DEFS). Among the most significant patterns, Acer opalus, Campanula trachelium, Cytisophyllum sessilifolium, Hippocrepis emerus, Lonicera etrusca and Sorbus aria were AFS, Acer campestre and Crataegus monogyna were RFS, Carthamus lanatus, Eryngium campestre and Genista pulchella were VRFS, and Bupleurum baldense and Ornithogalum umbellatum were DEFS. Lilium martagon, Melica uniflora and Poa nemoralis were only found in ancient or recent forests and thus could not be analysed with logistic regressions (Table 3). For further details, see Appendix S4.

\section{2 | Vegetation communities}

The three historical variables significantly explained the composition of understorey plant communities $(p<0.001)$. The effects of 1958 land use and forest continuity were stronger than the effect of 1860 land use $(0.13 \%, 0.18 \%$ and $0.11 \%$ of constrained inertia, respectively). Plant communities were structured according to increasing forest continuity on the CCA first factorial map (Figure 2a). Plots in forests that were deforested in 1958 were located at one extremity of the gradient of temporal continuity. On the CCA factorial maps, the vegetation plots were also distinguished according to 1860 land use: the first axis of the CCA separated forest from arable land while pasture was isolated from forest and arable land on the second axis (Figure 2b). The effect of 1958 land use was slightly different: the first axis separated forest from pasture and arable land and the second axis clearly differentiated arable land from forest and pasture (Figure 2c). The combination of forest continuity and past land use showed that plant community trajectories differed according to the type of previous land use, arable land or pasture, both developing on a gradient DEF-VRF-RF-AF (Figure 2d). Also, the difference between former pasture communities and former crop communities is more pronounced in very recent forests than in recent forests (Figure $2 \mathrm{~d}$ ).

\section{3 | Plant functional traits and ecological preferences}

\subsection{1 | Plant functional traits}

All three historical variables had an influence on plant traits. The first two axes of the RLQ accounted for $98 \%$ of the total inertia ( $84 \%$ and $14 \%$, respectively). The first ordination axis of the RLQ was related to forest temporal continuity (positive values: AF and RF; negative values: VRF and DEF), while the second axis was associated with past land use (positive values: arable land; negative values: pasture; Figure 4).

Trait responses were consistent among historical variables. For example, traits related to AF were also related to forests in 1860 (1860-F) and 1958 (1958-F), while traits related to former arable land in 1958 (1958-Ara) were also related to former arable land in 1860 (1860-Ara) (Figures 3 and 4).

Among Raunkiær life forms, only chamaephytes, phanerophytes and therophytes were influenced by historical variables. Chamaephytes were more frequent in 1958-Pas and less frequent in 1958-F. Phanerophytes were more frequent in 1860$F$, 1958-F, thus in AF and RF, but also in VRF. Therophytes were more frequent in 1860-Ara but less frequent in 1958-F, AF and RF (Figure 3). Malacophyllous, sclerophyllous and needle-type-leaved species were influenced by historical variables, but not microphyllous and graminean species. Malacophyllous species were less frequent in 1860-Pas and 1958-Pas while sclerophyllous species were more frequent in 1860-F, 1958-F and AF. Needle-like-leaved species were more frequent in 1860-Ara, 1958-Pas and VRF (Figure 3).

Plant height and leaf size similarly responded to the three historical variables: they displayed a positive relation with 1958-F, AF and RF, and a negative relation with 1860-Pas, 1958-Pas, VRF and DEF (Figure 3).

Annuals were more frequent in 1860-Ara and less frequent in 1958-For, AF and RF, while perennials were more frequent in 1958For and VRF (Figure 3).

Species with late end-of-flowering were more frequent in VRF and in former arable land (1860 and 1958) and were less frequent in former forests (1860, 1958 and AF; Figure 3). 
TABLE 3 Effect of land use in 1860, land use in 1958 and temporal continuity on 52 species of our dataset using logistic regression (species that most significantly responded to the historical variables)

\begin{tabular}{|c|c|c|c|c|}
\hline Species name & $\begin{array}{l}1860 \\
\text { LU }\end{array}$ & 1958 LU & $\begin{array}{l}\text { Temporal } \\
\text { continuity }\end{array}$ & $\begin{array}{l}\text { AF/ } \\
\text { RF }\end{array}$ \\
\hline Acer opalus & for* & for* & $\mathrm{AF}^{*}$ & $\mathrm{AF}^{*}$ \\
\hline $\begin{array}{l}\text { Aphyllanthes } \\
\text { monspeliensis }\end{array}$ & for* & for* & $\mathrm{AF}^{*}$ & \\
\hline $\begin{array}{l}\text { Brachypodium } \\
\text { rupestre }\end{array}$ & for* & for* & $\mathrm{AF}^{*}$ & $\mathrm{AF}^{*}$ \\
\hline Buxus sempervirens & for* & for* & $\mathrm{AF}^{*}$ & \\
\hline Campanula trachelium & for* & for* & $\mathrm{AF}^{*}$ & $\mathrm{AF}^{*}$ \\
\hline Carex halleriana & for & for* & $\mathrm{AF}^{*}$ & \\
\hline Cornus mas & for* & for* & $\mathrm{AF}^{*}$ & \\
\hline $\begin{array}{l}\text { Cytisophyllum } \\
\text { sessilifolium }\end{array}$ & for* & for* & $\mathrm{AF}^{*}$ & $\mathrm{AF}^{*}$ \\
\hline Genista hispanica & for* & for* & $\mathrm{AF}^{*}$ & \\
\hline Hedera helix & for* & for* & $\mathrm{AF}^{*}$ & \\
\hline Hippocrepis emerus & for* & for* & $\mathrm{AF}^{*}$ & $\mathrm{AF}^{*}$ \\
\hline Lilium martagon & NA & for (excl) & NA & \\
\hline Lonicera etrusca & for* & for* & $\mathrm{AF}^{*}$ & $\mathrm{AF}^{*}$ \\
\hline Lonicera implexa & for & for* & $\mathrm{AF}^{*}$ & \\
\hline Melica uniflora & NA & for (excl) & NA & \\
\hline Phillyrea latifolia & for* & for* & $\mathrm{AF}^{*}$ & $\mathrm{AF}^{*}$ \\
\hline Pinus halepensis & NS & for* & $\mathrm{AF}^{*}$ & \\
\hline Poa nemoralis & NA & for (excl) & NA & \\
\hline $\begin{array}{l}\text { Polypodium } \\
\text { cambricum }\end{array}$ & NS & for* & $\mathrm{AF}^{*}$ & \\
\hline $\begin{array}{l}\text { Polygonatum } \\
\text { odoratum }\end{array}$ & for* & for* & $\mathrm{AF}^{*}$ & $\mathrm{AF}^{*}$ \\
\hline Pseudoturritis turrita & for & for* & $\mathrm{AF}^{*}$ & \\
\hline Quercus ilex & for & for* & $\mathrm{AF}^{*}$ & \\
\hline Quercus pubescens & for* & for* & $\mathrm{AF}^{*}$ & \\
\hline Rhamnus alaternus & for* & for* & $\mathrm{AF}^{*}$ & $\mathrm{AF}^{*}$ \\
\hline Rubia peregrina & for* & for* & $\mathrm{AF}^{*}$ & \\
\hline Ruscus aculeatus & for & for* & $\mathrm{AF}^{*}$ & \\
\hline Sorbus aria & for* & for* & $\mathrm{AF}^{*}$ & $\mathrm{AF}^{*}$ \\
\hline Sorbus torminalis & for* & NS & $\mathrm{AF}^{*}$ & $\mathrm{AF}^{*}$ \\
\hline Teucrium chamaedrys & for* & for* & $\mathrm{AF}^{*}$ & $\mathrm{AF}^{*}$ \\
\hline Viburnum lantana & for* & for* & $\mathrm{AF}^{*}$ & \\
\hline Acer campestre & ara & for* & $\mathrm{RF}^{*}$ & \\
\hline Crataegus monogyna & ara & for* & $\mathrm{RF}^{*}$ & \\
\hline Inula conyza & NS & for* & $\mathrm{RF}^{*}$ & \\
\hline Ononis spinosa & pas & ara & $\mathrm{RF}^{*}$ & \\
\hline Phillyrea angustifolia & pas & for* & $\mathrm{RF}^{*}$ & \\
\hline Quercus coccifera & NS & for* & $\mathrm{RF}^{*}$ & \\
\hline Allium flavum & pas* & ara & VRF* $^{*}$ & \\
\hline Artemisia campestris & ara & ara* & VRF* $^{*}$ & \\
\hline
\end{tabular}

(Continues)
TABLE 3 (Continued)

\begin{tabular}{|c|c|c|c|c|}
\hline Species name & $\begin{array}{l}1860 \\
\text { LU }\end{array}$ & $1958 \mathrm{LU}$ & $\begin{array}{l}\text { Temporal } \\
\text { continuity }\end{array}$ & $\begin{array}{l}\text { AF/ } \\
\text { RF }\end{array}$ \\
\hline Avena barbata & ara & pas* & VRF* $^{*}$ & \\
\hline Carthamus lanatus & ara & ara* & VRF* & \\
\hline $\begin{array}{c}\text { Convolvulus } \\
\text { cantabrica }\end{array}$ & pas* & pas* & VRF* & \\
\hline Echinops ritro & ara* & ara* & VRF* & \\
\hline Eryngium campestre & ara* & ara & VRF* & \\
\hline Genista pulchella & pas & pas* & VRF* & \\
\hline Linum strictum & ara* & pas* & VRF* & \\
\hline Potentilla cinerea & pas & pas* & VRF* & \\
\hline Reichardia picroides & ara & pas* & VRF* & \\
\hline Reseda phyteuma & ara & ara* & VRF* & \\
\hline Bupleurum baldense & for & ara* & DEF* & \\
\hline Galium corrudifolium & for* & pas & $\mathrm{DEF}^{*}$ & \\
\hline $\begin{array}{c}\text { Ornithogalum } \\
\text { umbellatum }\end{array}$ & for & pas* & DEF* & \\
\hline Valeriana tuberosa & for* & pas* & DEF* & \\
\hline
\end{tabular}

Note: The effect of forest age (AF/RF where RF = RF and VRF) was also added (last column). Species significantly responding to a single historical variable while taking local conditions into account are labelled with an asterisk ( $\triangle \mathrm{AIC}>2$ ) and species preferences are in bold when $\triangle \mathrm{AIC}>5$. Species with no asterisk responded to the historical variable but not when taking local conditions into account. NA stands for species that could not be tested; AF, ancient forest; ara, arable land; $D E F$, temporarily deforested; for, forest; NS, non-significant; pas, pasture; RF, recent forest; VRF, very recent forest. Species only found in ancient or recent forests are indicated as exclusive (excl).

Historical variables had an effect on anemochores, endozoochores and epizoochores, but not on barochores and myrmecochores. Anemochores were less frequent in AF, epizoochores were more frequent in 1958-Ara, while endozoochores were more frequent in former forests (1860, 1958 and AF; Figure 3).

\subsection{2 | Ecological preferences}

Historical variables had strong effects on ecological preferences (Figure 3). Forest species were more frequent only in AF, while forest edge species were more frequent in all trajectories of former forests (1860 and 1958, AF and RF) and open-habitat species were more frequent in DEF, but less frequent in AF. The response of soil moisture and nitrogen indicator values (IV) to historical variables was rather similar and opposite to the response of light IV (Figures 3, 4). Light IV was higher in former pastures (1860 and 1958) and in VRF and DEF, but lower in former forests (1860 and 1958), while soil moisture and nitrogen IV were higher in AF and 1958 forests, but lower in former pastures (1860 and 1958 for nitrogen IV and 1958 for soil moisture IV) and in VRF and DEF (Figure 3). 


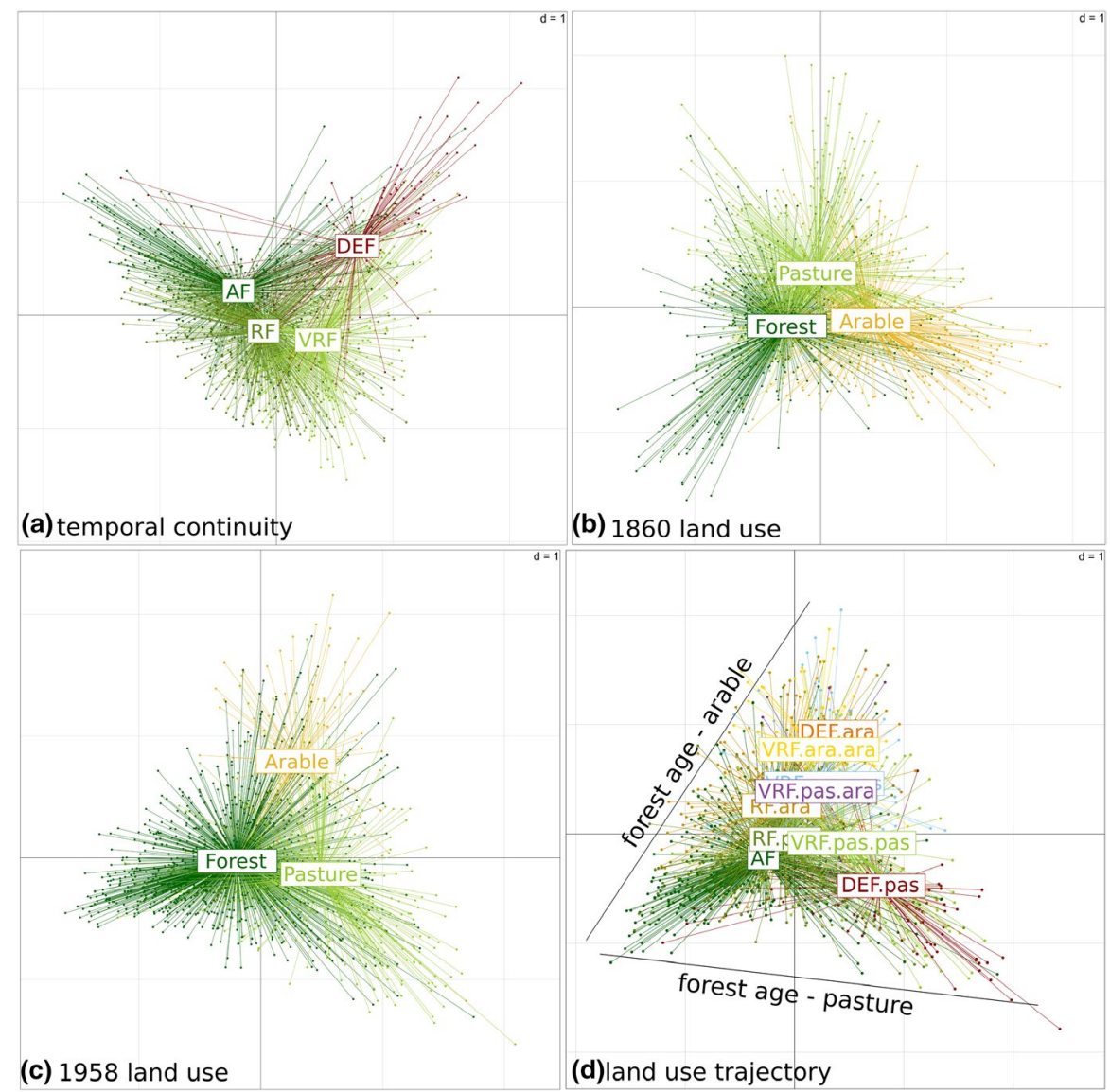

FIGURE 2 Canonical correspondence analysis (CCA) first factorial map according to: (a) forest temporal continuity; (b) 1860 land use; (c) 1958 land use; and (d) land use trajectory, i.e., the combination of the three historical variables. The four CCAs were constrained by the corresponding historical variables. AF, ancient forest; RF.pas, recent forest developed on 1860 pasture; RF.ara, recent forest developed on 1860 arable land; VRF.pas.pas, very recent forest developed on pasture (1860 and 1958), VRF.ara.ara, very recent forest developed on arable land (1860 and 1958), VRF.ara.pas, very recent forest developed on arable land (1860) and then pasture (1958); VRF.pas.ara, very recent forest developed on pasture (1860) and then arable land (1958); DEF.ara, deforested into arable land in 1958; DEF.pas, deforested into pasture in 1958

\section{4 | DISCUSSION}

Globally, our results underlined that land use history over centuries in the Mediterranean region had legacy effects on understorey plant species communities and traits. We could have expected less strong responses since our study area is densely forested and newly established forests are connected to already existing forests (Abadie, Dupouey, et al., 2018). This may thus imply that landscape configuration is not, in our case, a driver of differentiation of vegetation communities among forests of differing land use history.

\subsection{Ancient forest species in the Mediterranean}

Fifty-seven species were associated with ancient forests. They were dominantly forest specialists or forest edge species, with low light indicator value, and higher nitrogen and soil moisture indicator values. Among them, phanerophytes, endozoochores and sclerophyllous species with larger leaves and a higher potential maximum height were dominant. In temperate lowlands, phanerophytes and endozoochores are associated with recent forests (Bergès et al., 2016; Sciama et al., 2009), while ancient forests are characterised by myrmecochorous species (Bergès et al., 2016), which display a shorter dispersal distance than species with other dispersal syndromes (Vittoz \& Engler, 2007). In our study, myrmecochorous species were not associated with ancient forests while phanerophytes and endozoochores were clearly associated with ancient forests. Phanerophytes are much more diversified and thus represented more in Mediterranean forests than in temperate forests (Quézel and Médail, 2003; Gauquelin et al., 2018). However, we still have to clarify why they characterise ancient Mediterranean forests, but not temperate ones. Myrmecochores are overall under-represented in the Mediterranean forest flora (Wolff \& Debussche, 1999). We could thus only suppose that they had disappeared from forests with a long-time overexploitation, which were coppiced, grazed and even temporarily cultivated (Gilbert, 1989), or that the Mediterranean context implies other dispersal syndromes than temperate regions. 


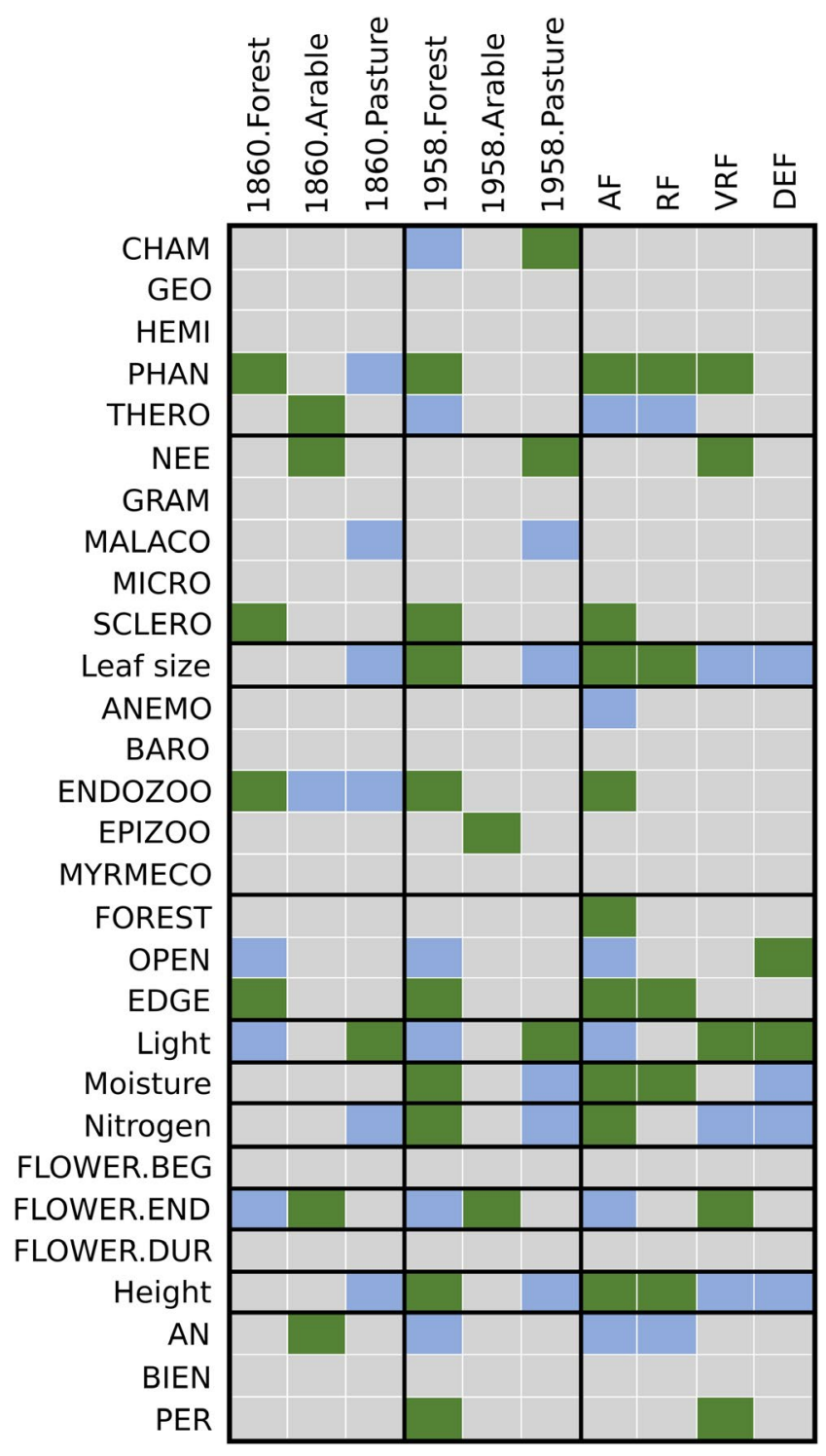

FIGURE 3 Relation between plant functional traits and ecological preferences, and historical variables (1860 land use, 1958 land use and forest continuity). AF, ancient forest; RF, recent forest; VRF, very recent forest; DEF, deforested in 1958. Significant positive relationships are in green and negative relationships in blue $(p<.05)$. See Appendix S5 for detailed $p$-values

In a region where forests have been subject to fires over a long time span, phanerophytes might also have been favoured over herbaceous species alongside the evolution of forests. Further studies would be necessary to compare trait differences in ancient and recent forests in other biogeographical contexts .

\subsection{Contrasted legacies of former crop and pasture on understorey vegetation}

Consistently with our hypothesis, our results indicate that former arable and pastoral use displayed different legacies in current understorey plant communities, traits and ecological preferences.
Although communities of former pastures differed from ancient forest communities, the legacies of former arable land were stronger than the legacies of former pastures, as was highlighted in temperate regions by Koerner et al. (1997).

In 1860 and 1958 in the PNRL, pastures and forests were principally located on unproductive land (Abadie, Dupouey, et al., 2018). Depending on grazing intensity, pastoral use may have impoverished soils even more (McLauchlan, 2006). Forest developed on those soils may thus need a long time to grow and be characterised by smaller trees and many gaps in canopy cover, thus providing a brighter, more xeric environment for understorey plant species. Thus, differences in abiotic conditions between arable land and pastures could explain why plant indicator values for light and for soil moisture were positively and negatively associated with former pastures, respectively.

Conversely, former crops were more often located on the most productive land in 1860 and 1958, i.e., the deepest soils on loose substrates (Abadie, Dupouey, et al., 2018). Nevertheless, agricultural use was first abandoned on the least suitable land for crops, i.e., on steeper slopes and closer to pre-existing forest compared to the land still cultivated (Abadie, Dupouey, et al., 2018). Most of this abandoned arable land might have been cultivated as terraced cropland, and thus provide deeper and more productive soils (Arnaez, LanaRenault, Lasanta, Ruiz-Flano, \& Castroviejo, 2015; Stanchi, Freppaz, Agnelli, Reinsch, \& Zanini, 2012; Tarolli, Preti, \& Romano, 2014). Nitrophilous and mesophilous species could then find favourable conditions to develop on former arable land. Besides, tree canopy probably closed faster, allowing shade-tolerant and less competitive species to develop with increasing forest continuity.

\section{3 | Forest temporal continuity: a long-term successional process}

Understorey communities in recent forests became more and more similar to those in ancient forest communities with time (Figure 2), which confirms our second hypothesis of a long-term secondary succession in Mediterranean forests following agricultural abandonment. We observed an increasing proportion of forest species (sciaphillous, phanerophytes) and endozoochores and a decreasing proportion of open-habitat species (heliophilous, therophytes) and epizoochores with increasing forest temporal continuity (Aubin, Messier, \& Bouchard, 2008; Tatoni \& Roche, 1994). The gradient of the indicator value for light according to forest temporal continuity reflected a lighter environment in more recent forests, as observed in temperate regions (Bergès et al., 2016; Brudvig, Grman, Habeck, Orrock, \& Ledvina, 2013; Glitzenstein, Canham, McDonnell, \& Streng, 1990). These patterns reflect the development of the canopy cover along with forest succession and the disappearance of openhabitat species with successional age of the forest (Finegan, 1984), as also demonstrated by Amici et al. (2013) in a Mediterranean context.

Confirming our third hypothesis, the difference in vegetation communities between former arable land and former pastures were more pronounced in very recent forests compared to recent forests. 


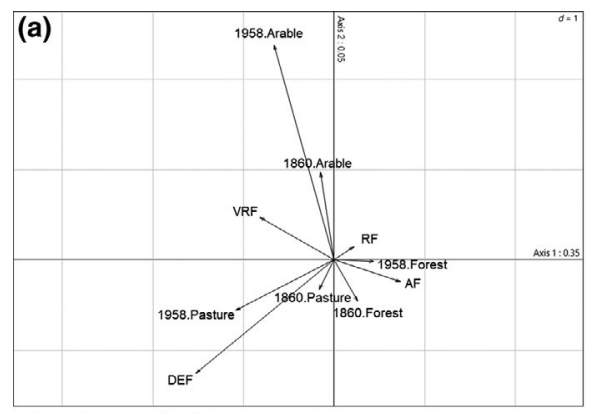

Land use trajectory

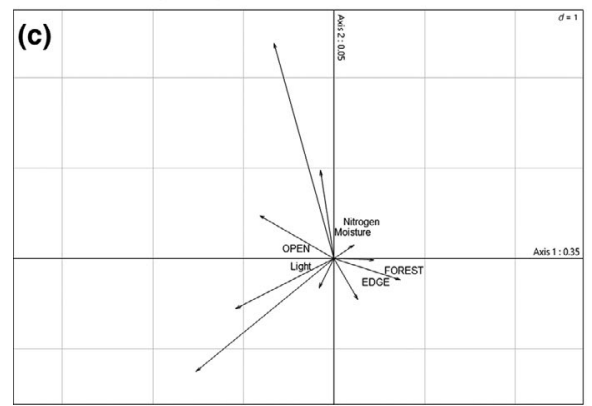

Land use trajectory and ecological preferences

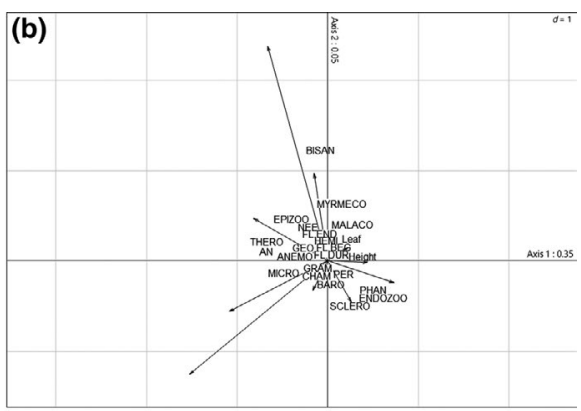

Land use trajectory and plant functional traits

FIGURE 4 First RLQ factorial map of (a) land use trajectory - AF, ancient forest; DEF, deforested in 1958; RF, recent forest; VRF, very recent forest; (b) land use trajectory and plant functional traits - AN, annuals; ANEMO, anemochores; BARO, baro-, auto- \& hydrochores; BIS, biennials; CHAM, chamæphytes; ENDOZOO, endozoo- \& dyszoochores; EPIZOO, epizoochores; FL.BEG, beginning of flowering season; FL.DUR, duration of flowering season; FL.END, end-of-flowering season; GEO, geophytes; GRAM, graminean; HEMI, hemicryptophytes; MALACO, malacophyllous; MICRO, microphyllous; MYRMECO, myrmecochores; NEE, needles, spines, scales and succulent; PER, perennials; PHAN, phanerophytes; SCLERO, sclerophyllous and laurel-like; THERO, therophytes; (c) land use trajectory and ecological preferences EDGE, forest edge species; FOREST, forest species; OPEN, open-habitat species

Since 1860, newly established forests developed adjacent to already existing forests (Abadie, Dupouey, et al., 2018), thus reducing the dispersal limitation of species for colonising the newly established forests (Flinn \& Vellend, 2005; Graae, Sunde, \& Fritzboger, 2003; Hermy \& Verheyen, 2007). The colonisation credit of recent forests in our study might thus have already been exhausted, contrary to very recent forests. For the same reason, these very recent forests were also closer to open-habitat edge (Bergès et al., 2016). This edge effect could thus add to the effect of forest temporal continuity on plant species (Bergès et al., 2016).

Several open-habitat species persisted after land abandonment and forest development. Two ecological processes can explain this maintenance: either suitable habitats remained within the forest landscape (open areas within a closed forest matrix), or those species exhibited an extinction debt, meaning that they have remained while their optimum habitat has already disappeared (Jackson \& Sax, 2010). This extinction debt can last over more than a century (Vellend et al., 2006). A long-term survey on those species would be necessary to disentangle the extent of the two processes.

\section{4 | Legacies of a temporal deforestation}

The temporal deforestation (DEF) seemed to imply legacies of its own. Forests that were deforested between 1860 and 2010 accounted only for $6 \%$ of our plots, but no less than 87 species were associated with this land use trajectory. Plant communities associated with temporarily deforested land were the most distinct from those of ancient forests and the traits and ecological preferences associated with DEF were also associated with VRF and had an opposite relation with AF or RF (e.g., leaf size, plant height, and indicator values). The temporal deforestation may thus have erased species present in formerly ancient forests (De Keersmaeker, 2013; Verheyen, Honnay, Motzkin, Hermy, \& Foster, 2003). All this suggests that legacies of a temporary deforestation of ancient forests were different from those of the continuous agricultural use until the mid-20th century.

The temporal deforestation to arable land showed similar legacies as long-term arable use, which can be explained by thorough nutrient inputs and ploughing in the 19th century.

Concerning the temporal deforestation to pasture, those differences might be due to an actual temporary deforestation by fire. Of the 97 plots in this temporal trajectory, 91 were photo-interpreted as garrigue (associated with pasture, Table 1). The repetition of forest wildfires leads to the development of garrigue (Tatoni, 1992). The PNRL has been spared by forest fires during the last decades, but some intensive and repeated fires occurred during the 1940s and 1950 s on the eastern part of the Luberon mountain. Associated to violent rain episodes (Varese, 1990), repeated fires contributed to the erosion and impoverishment of soils, where the garrigue developed (Tatoni, 1992) and turned into an open forest where therophytes and anemochores were dominant, facilitated by the lighter conditions of 
those post-fire conditions (Bonnet \& Tatoni, 2003). This result questions the definition of ancient forests: "a forest that may not have been used for agricultural purposes" (Marks \& Gardescu, 2001). This definition implies that a forest fire, which does not affect the soil like ploughing does, would not interrupt the temporal continuity of an ancient forest. Here we suggest that the definition of ancient forest should probably exclude forests that experienced repeated fires. However, supplementary investigations would be necessary to confirm this assumption.

\section{5 | Implications for conservation}

In temperate lowlands, most ancient forests are isolated within a more or less intensive agricultural matrix (De Keersmaeker et al., 2015; Rackham, 2008). The conservation of the forest continuum is thus a major issue, as it would help the colonisation of newly established forests by ancient forest species. In our context, the restoration of a spatial forest continuum between ancient forest patches naturally took place with the natural forest recovery since the 19th century (Abadie, Dupouey, et al., 2018). The conservation of ancient forest species depends more on the use of the forest. Although this has yet to be proven, a former overexploitation of Mediterranean forests might have resulted in the disappearance of some herbaceous ancient forest species. Nevertheless, forest specialists are associated with ancient forests. It is therefore crucial to conserve ancient forests to ensure the conservation of forest specialists.

\section{5 | CONCLUSION AND PERSPECTIVES}

With this study, we first highlighted that long-term land use legacy in Mediterranean forest understorey plant communities lasts over 150 years, making it comparable to the well-known legacy identified in temperate lowlands (Hermy \& Verheyen, 2007). We also showed that the type of past land use prior to forest resulted in distinct plant successions.

In former studies, the effect of forest temporal continuity and past land use mostly concerned soil physico-chemical properties and vegetation (Bergès et al., 2017; Flinn \& Vellend, 2005; Hermy \& Verheyen, 2007), but now focuses more and more on other species groups with low dispersal abilities, such as saproxylic beetles, snails, collembola, etc. (Janssen, 2016; Janssen et al., 2018; Vrignaud, 2016). Exploring those taxonomic groups could be very informative in the Mediterranean region. Furthermore, exploring the interaction between fire regimes and past land use on current forest ecosystems would help understand the functioning of forest ecosystems (Duguy, Rovira, \& Vallejo, 2007; Duguy \& Vallejo, 2008; Puerta-Pinero et al., 2012).

\section{ACKNOWLEDGEMENTS}

The authors would like to thank Virgile Noble for letting them access the SILENE database. We also thank Philip Roche, Renato Henriques and Jordi Prats for their constructive comments.

\section{AUTHOR CONTRIBUTIONS}

JA, JLD, AS and LB conceived of the research ideas; JA and NV collected data; JA performed statistical analyses; JA, with contributions from LB, CA and JLD, wrote the paper; all authors discussed the results and commented on the manuscript.

\section{DATA AVAILABILITY STATEMENT}

Primary datasets and scripts are stored in an internal repository without DOI, but are available for re-analyses upon request.

\section{ORCID}

Juliet Abadie (iD https://orcid.org/0000-0003-2493-2948

Laurent Bergès iD https://orcid.org/0000-0003-0408-7900

\section{REFERENCES}

Abadie, J., Avon, C., Dupouey, J. L., Lopez, J. M., Tatoni, T., \& Bergès, L. (2018a). Land use legacies on forest understory vegetation and soils in the Mediterranean region: Should we use historical maps or in situ land use remnants? Forest Ecology and Management, 427, 17-25. https://doi.org/10.1016/j.foreco.2018.05.050

Abadie, J., Dupouey, J. L., Avon, C., Rochel, X., Tatoni, T., \& Bergès, L. (2018b). Forest recovery since 1860 in a Mediterranean region: Drivers and implications for land use and land cover spatial distribution. Landscape Ecology, 33, 289-305. https://doi.org/10.1007/s1098 0-017-0601-0

Amici, V., Santi, E., Filibeck, G., Diekmann, M., Geri, F., Landi, S., ... Chiarucci, A. (2013). Influence of secondary forest succession on plant diversity patterns in a Mediterranean landscape. Journal of Biogeography, 40, 2335-2347. https://doi.org/10.1111/jbi.12182

Arnaez, J., Lana-Renault, N., Lasanta, T., Ruiz-Flano, P., \& Castroviejo, J. (2015). Effects of farming terraces on hydrological and geomorphological processes. A review. Catena, 128, 122-134. https://doi. org/10.1016/j.catena.2015.01.021

Aubin, I., Messier, C., \& Bouchard, A. (2008). Can plantations develop understory biological and physical attributes of naturally regenerated forests? Biological Conservation, 141, 2461-2476. https://doi. org/10.1016/j.biocon.2008.07.007

Baeten, L., Hermy, M., \& Verheyen, K. (2009). Environmental limitation contributes to the differential colonization capacity of two forest herbs. Journal of Vegetation Science, 20, 209-223. https://doi. org/10.1111/j.1654-1103.2009.05595.x

Basnou, C., Vicente, P., Espelta, J. M., \& Pino, J. (2016). Of niche differentiation, dispersal ability and historical legacies: What drives woody community assembly in recent Mediterranean forests? Oikos, 125, 107-116.

Bellemare, J., Motzkin, G., \& Foster, D. R. (2002). Legacies of the agricultural past in the forested present: An assessment of historical land-use effects on rich mesic forests. Journal of Biogeography, 29, 1401-1420. https://doi.org/10.1046/j.1365-2699.2002.00762.x

Bergès, L., Avon, C., Arnaudet, L., Archaux, F., Chauchard, S., \& Dupouey, J. L. (2016). Past landscape explains forest periphery-to-core gradient of understorey plant communities in a reforestation context. Diversity and Distributions, 22, 3-16. https://doi.org/10.1111/ ddi.12384

Bergès, L., Feiss, T., Avon, C., Martin, H., Rochel, X., Dauffy-Richard, E., ... Dupouey, J.-L. (2017). Response of understorey plant communities and traits to past land use and coniferous plantation. Applied Vegetation Science, 20, 468-481. https://doi.org/10.1111/avsc.12296

Bonnet, V., \& Tatoni, T. (2003). Analyse spatiale et fonctionnelle de la réponse de la végétation après incendie en basse Provence calcaire. Forêt Méditerranéenne XXIV, 385-402. 
Bossuyt, B., Heyn, M., \& Hermy, M. (2002). Seed bank and vegetation composition of forest stands of varying age in central Belgium: Consequences for regeneration of ancient forest vegetation. Plant Ecology, 162, 33-48.

Brudvig, L. A., Grman, E., Habeck, C. W., Orrock, J. L., \& Ledvina, J. A. (2013). Strong legacy of agricultural land use on soils and understory plant communities in longleaf pine woodlands. Forest Ecology and Management, 310, 944-955. https://doi.org/10.1016/j. foreco.2013.09.053

Brunet, J., De Frenne, P., Holmstrom, E., \& Mayr, M. L. (2012). Lifehistory traits explain rapid colonization of young post-agricultural forests by understory herbs. Forest Ecology and Management, 278, 55-62. https://doi.org/10.1016/j.foreco.2012.05.002

Chalvet, M. (2006). Paysages et conflits en Provence. Rives nord-méditerranéennes, 23, 11-26.

Cinotti, B. (1996). Evolution des surfaces boisées en France : Proposition de reconstitution depuis le début du XIX ${ }^{\mathrm{ème}}$ siècle. Revue Forestière Française, 48, 547-562.

De Frenne, P., Baeten, L., Graae, B. J., Brunet, J., Wulf, M., Orczewska, A., ... Verheyen, K. (2011). Interregional variation in the floristic recovery of post-agricultural forests. Journal of Ecology, 99, 600-609. https:// doi.org/10.1111/j.1365-2745.2010.01768.x

De Keersmaeker, L. (2013). Spatio-temporal patterns of vegetation recovery in post-agricultural forests in Flanders. PhD thesis in Applied Biological Sciences, Land \& Forest Management. Ghent, Belgium: Ghent University.

De Keersmaeker, L., Onkelinx, T., De Vos, B., Rogiers, N., Vandekerkhove, K., Thomaes, A., ... Verheyen, K. (2015). The analysis of spatio-temporal forest changes (1775-2000) in Flanders (northern Belgium) indicates habitat-specific levels of fragmentation and area loss. Landscape Ecology, 30, 247-259. https://doi.org/10.1007/s1098 0-014-0119-7

Dray, S., Choler, P., Doledec, S., Peres-Neto, P. R., Thuiller, W., Pavoine, S., \& ter Braak, C. J. F. (2014). Combining the fourth-corner and the RLQ methods for assessing trait responses to environmental variation. Ecology, 95, 14-21. https://doi.org/10.1890/13-0196.1

Dray, S., \& Dufour, A. B. (2007). The ade4 package: Implementing the duality diagram for ecologists. Journal of Statistical Software, 22, 1-20.

Duguy, B., Rovira, P., \& Vallejo, R. (2007). Land-use history and fire effects on soil fertility in eastern Spain. European Journal of Soil Science, 58, 83-91. https://doi.org/10.1111/j.1365-2389.2006.00802.x

Duguy, B., \& Vallejo, V. R. (2008). Land-use and fire history effects on post-fire vegetation dynamics in eastern Spain. Journal of Vegetation Science, 19, 97-108. https://doi.org/10.3170/2007-8-18336

Dupouey, J. L., Dambrine, E., Laffite, J. D., \& Moares, C. (2002). Irreversible impact of past land use on forest soils and biodiversity. Ecology, 83, 2978-2984. https://doi.org/10.1890/00129658(2002)083[2978:IIOPLU]2.0.CO;2

Dyer, J. M. (2010). Land-use legacies in a central Appalachian forest: Differential response of trees and herbs to historic agricultural practices. Applied Vegetation Science, 13, 195-206. https://doi. org/10.1111/j.1654-109X.2009.01061.x

Favre, C., Grel, A., Granier, E., Cosserat-Mangeot, R., Bachacou, J., \& Dupouey, J. L. (2013). Digitalisation des cartes anciennes. Manuel pour la vectorisation de l'usage des sols et le géoréférencement des minutes 1: 40,000 de la carte d'Etat-Major (v. 12.7.3) (pp. 54). Champenoux, France: INRA, Nancy.

Finegan, B. (1984). Forest succession. Nature, 312, 109-114. https://doi. org/10.1038/312109a0

Flinn, K. M., \& Vellend, M. (2005). Recovery of forest plant communities in post-agricultural landscapes. Frontiers in Ecology and the Environment, 3, 243-250. https://doi.org/10.1890/15409295(2005)003[0243:ROFPCI]2.0.CO;2

Flinn, K. M., Vellend, M., \& Marks, P. L. (2005). Environmental causes and consequences of forest clearance and agricultural abandonment in central New York, USA. Journal of Biogeography, 32, 439-452. https://doi.org/10.1111/j.1365-2699.2004.01198.x

Fourchy, P. (1963). Les lois du 28 juillet 1860 et 8 juin 1864 sur le reboisement et le gazonnement des montagnes. Revue De Géographie Alpine, 51, 19-41. https://doi.org/10.3406/rga.1963.3115

Gachet, S., Vela, E., \& Tatoni, T. (2005). BASECO: A floristic and ecological database of Mediterranean French flora. Biodiversity and Conservation, 14, 1023-1034. https://doi.org/10.1007/s1053 1-004-8411-5

Gargominy, O., Tercerie, S., Régnier, C., Ramage, T., Schoelinck, C., Dupont, P., ... Poncet, L. (2014). TAXREF v8.0, référentiel taxonomique pour la France : méthodologie, mise en œuvre et diffusion. Paris, France: Muséum national d'Histoire naturelle. Rapport SPN 2014-42. 126 pp.

Gauquelin, T., Michon, G., Joffre, R., Duponnois, R., Génin, D., Fady, B., ... Baldy, V. (2018). Mediterranean forests, land use and climate change: A social-ecological perspective. Regional Environmental Change, 18, 623-636.

Gilbert, Y. (1989). Elevage, forêt et société. Analyse socio-historique. Forêt Méditerranéenne, XI, 203-216.

Glitzenstein, J. S., Canham, C. D., McDonnell, M. J., \& Streng, D. R. (1990). Effects of environment and land-use history on upland forests of the Cary-Arboretum, Hudson Valley, New-York. Bulletin of the Torrey Botanical Club, 117, 106-122. https://doi.org/10.2307/2997050

Graae, B. J., Hansen, T., \& Sunde, P. B. (2004). The importance of recruitment limitation in forest plant species colonization: A seed sowing experiment. Flora, 199, 263-270. https://doi. org/10.1078/0367-2530-00154

Graae, B. J., Sunde, P. B., \& Fritzboger, B. (2003). Vegetation and soil differences in ancient opposed to new forests. Forest Ecology and Management, 177, 179-190. https://doi.org/10.1016/S0378 -1127(02)00438-3

Grove, A. T., \& Rackham, O. (2001). The nature of Mediterranean Europe: An ecological history. New Haven, CT: Yale University Press.

Guarino, R., Domina, G., \& Pignatti, S. (2012). Ellenberg's indicator values for the Flora of Italy - first update: Pteridophyta, Gymnospermae and Monocotyledoneae. Flora Mediterranea, 22, 197-209.

Hermy, M., \& Verheyen, K. (2007). Legacies of the past in the present-day forest biodiversity: A review of past land-use effects on forest plant species composition and diversity. Ecological Research, 22, 361-371. https://doi.org/10.1007/s11284-007-0354-3

Hodgson, J. G., Wilson, P. J., Hunt, R., Grime, J. P., \& Thompson, K. (1999). Allocating C-S-R plant functional types: A soft approach to a hard problem. Oikos, 85, 282-294. https://doi.org/10.2307/3546494

Holmes, M. A., \& Matlack, G. R. (2018). Assembling the forest herb community after abandonment from agriculture: Long-term successional dynamics differ with land-use history. Journal of Ecology, 106, 21212131. https://doi.org/10.1111/1365-2745.12970

Jackson, S. T., \& Sax, D. F. (2010). Balancing biodiversity in a changing environment: Extinction debt, immigration credit and species turnover. Trends in Ecology \& Evolution, 25, 153-160.

Janssen, P. (2016). Influences relatives de l'ancienneté et de la maturité sur la biodiversité : Implications pour la conservation en forêts de montagne. Grenoble, France: Université Grenoble Alpes.

Janssen, P., Bec, S., Fuhr, M., Taberlet, P., Brun, J.-J., \& Bouget, C. (2018). Present conditions may mediate the legacy effect of past land-use changes on species richness and composition of above- and below-ground assemblages. Journal of Ecology, 106, 306-318. https:// doi.org/10.1111/1365-2745.12808

Julve, P. (1998). Baseflor. Index botanique, écologique et chorologique de la flore de France. Version: "17 juin 2016". http://perso.wanadoo.fr/ philippe.julve/catminat.htm

Kimberley, A., Blackburn, G. A., Whyatt, J. D., Kirby, K., \& Smart, S. M. (2013). Identifying the trait syndromes of conservation indicator species: How distinct are British ancient woodland indicator plants 
from other woodland species? Applied Vegetation Science, 16, 667675. https://doi.org/10.1111/avsc.12047

Koerner, W., Cinotti, B., Jussy, J. H., \& Benoît, M. (2000). Evolution des surfaces boisées en France depuis le début du XIXe siècle : Identification et localisation des boisements des territoires agricoles abandonnés. Revue Forestière Française, 52, 249-269.

Koerner, W., Dupouey, J. L., Dambrine, E., \& Benoit, M. (1997). Influence of past land use on the vegetation and soils of present day forest in the Vosges mountains, France. Journal of Ecology, 85, 351-358. https://doi.org/10.2307/2960507

Kouba, Y., Martinez-Garcia, F., de Frutos, A., \& Alados, C. L. (2015). Effects of previous land-use on plant species composition and diversity in Mediterranean forests. PLoS ONE, 10. https://doi.org/10.1371/journ al.pone. 0139031

Legendre, P., \& Legendre, L. (1998). Numerical ecology. Amsterdan, The Netherlands: Elsevier.

Marks, P. L., \& Gardescu, S. (2001). Inferring forest stand history from observational field evidence. In D. Egan, \& E. A. Howell (Eds.), The historical ecology handbook: A restorationist's guide ro reference ecosystems. Washington D.C.: Island Press.

Mather, A. S., Fairbairn, J., \& Needle, C. L. (1999). The course and drivers of the forest transition: The case of France. Journal of Rural Studies, 15, 65-90. https://doi.org/10.1016/S0743-0167(98)00023-0

McLauchlan, K. (2006). The nature and longevity of agricultural impacts on soil carbon and nutrients: A review. Ecosystems, 9, 1364-1382. https://doi.org/10.1007/s10021-005-0135-1

Médail, F., \& Diadema, K. (2009). Glacial refugia influence plant diversity patterns in the Mediterranean basin. Journal of Biogeography, 36, 1333-1345. https://doi.org/10.1111/j.1365-2699.2008.02051.x

Pignatti, S., Menegoni, P., \& Pietrosanti, S. (2005). Bioindicazione attraverso le piante vascolari. Valori di indicazione secondo Ellenberg (Zeigerwerte) per le specie della Flora d'Italia. Braun-Blanquetia, 39, 1-97.

Plue, J., Hermy, M., Verheyen, K., Thuillier, P., Saguez, R., \& Decocq, G. (2008). Persistent changes in forest vegetation and seed bank 1,600 years after human occupation. Landscape Ecology, 23, 673-688.

Puerta-Pinero, C., Espelta, J. M., Sanchez-Humanes, B., Rodrigo, A., Coll, L., \& Brotons, L. (2012). History matters: Previous land use changes determine post-fire vegetation recovery in forested Mediterranean landscapes. Forest Ecology and Management, 279, 121-127. https:// doi.org/10.1016/j.foreco.2012.05.020

Quézel, P., Médail, F., 2003. Que faut-il entendre par "forêts méditerranéennes" ? Forêt Méditerranéenne XXIV. 11-31.

R Development Core Team. (2017). R: a language and environment for statistical computing. Vienna, Austria: R Foundation for Statistical Computing.

Rackham, O. (2008). Ancient woodlands: Modern threats. New Phytologist, 180, 571-586. https://doi.org/10.1111/j.1469-8137.2008.02579.x

Salvaudon, A., Hamel, A., Grel, A., Rossi, M., \& Vallauri, D. (2012). Notice de la carte des forêts anciennes du Parc Naturel Régional du Lubéron (1:40,000) avec référence aux autres usages du sol (pp. 18).

Sciama, D., Augusto, L., Dupouey, J. L., Gonzalez, M., \& Dominguez, C. M. (2009). Floristic and ecological differences between recent and ancient forests growing on non-acidic soils. Forest Ecology and Management, 258, 600-608. https://doi.org/10.1016/j. foreco.2009.04.027

Singleton, R., Gardescu, S., Marks, P. L., \& Geber, M. A. (2001). Forest herb colonization of postagricultural forests in central New York State, USA. Journal of Ecology, 89, 325-338. https://doi. org/10.1046/j.1365-2745.2001.00554.x

Stanchi, S., Freppaz, M., Agnelli, A., Reinsch, T., \& Zanini, E. (2012). Properties, best management practices and conservation of terraced soils in Southern Europe (from Mediterranean areas to the Alps): A review. Quaternary International, 265, 90-100.
Stover, M. E., \& Marks, P. L. (1998). Successional vegetation on abandoned cultivated and pastured land in Tompkins County, New York. Journal of the Torrey Botanical Society, 125, 150-164. https://doi. org/10.2307/2997302

Taillefumier, F., \& Piegay, H. (2003). Contemporary land use changes in prealpine Mediterranean mountains: A multivariate GIS-based approach applied to two municipalities in the Southern French Prealps. Catena, 51, 267-296. https://doi.org/10.1016/S0341 -8162(02)00168-6

Tarolli, P., Preti, F., \& Romano, N. (2014). Terraced landscapes: From an old best practice to a potential hazard for soil degradation due to land abandonment. Anthropocene, 6, 10-25. https://doi.org/10.1016/j. ancene.2014.03.002

Tatoni, T. (1992). Evolution post-culturale des agrosystèmes de terrasses en Provence calcaire: phytoécologie et impact humain. Aix-Marseille 1.

Tatoni, T., \& Roche, P. (1994). Comparison of old-field and forest revegetation dynamics in Provence. Journal of Vegetation Science, 5, 295302. https://doi.org/10.2307/3235852

Tison, J.-M., Jauzein, P., \& Michaud, H. (2014). Flore de la France méditerranéenne continentale. Turriers, France: Naturalia Publications, CBNMed.

Varese, P. (1990). Pré-étude en vue d'une typologie des stations forestières du Luberon (pp. 141). Apt, France: Parc Naturel Régional du Luberon.

Vellend, M., Verheyen, K., Jacquemyn, H., Kolb, A., Van Calster, H., Peterken, G., \& Hermy, M. (2006). Extinction debt of forest plants persists for more than a century following habitat fragmentation. Ecology, 87, 542-548. https://doi.org/10.1890/05-1182

Verheyen, K., Honnay, O., Motzkin, G., Hermy, M., \& Foster, D. R. (2003). Response of forest plant species to land-use change: A life-history trait-based approach. Journal of Ecology, 91, 563-577. https://doi. org/10.1046/j.1365-2745.2003.00789.x

Vittoz, P., \& Engler, R. (2007). Seed dispersal distances: A typology based on dispersal modes and plant traits. Botanica Helvetica, 117, 109-124. https://doi.org/10.1007/s00035-007-0797-8

Vrignaud, S. (2016). Les gastéropodes et les forêts anciennes. ChavaniacLafayette, France: CBN Massif Central.

Wolff, A., \& Debussche, M. (1999). Ants as seed dispersers in a Mediterranean old-field succession. Oikos, 84, 443. https://doi. org/10.2307/3546423

\section{SUPPORTING INFORMATION}

Additional supporting information may be found online in the Supporting Information section.

Appendix S1. Methodology for vegetation plot selection Appendix S2. Details on plant traits and ecological preferences Appendix S3. Description of environmental covariates

Appendix S4. Result of the logistic regressions for the whole dataset Appendix S5. Fourth-corner tests for bivariate associations between plant traits and historical variables

How to cite this article: Abadie J, Dupouey J-L, Salvaudon A, et al. Historical ecology of Mediterranean forests: Land use legacies on current understorey plants differ with time since abandonment and former agricultural use. J Veg Sci. 2020;00:1-13. https://doi.org/10.1111/jvs.12860 